\title{
MAGYARORSZÁG ÉS AZ EURÓPAI ALKOTMÁNYOZÁSI FOLYAMAT: AZ EURÓPAI KONVENT
}

\author{
(Hungary and the European Constitutional Process: \\ the European Convent)
}

\author{
GRÚBER KÁROLY
}

Kulcsszavak:

Európai Alkotmány Európai Konvent

Az Európai Unió jövöje szempontjából alapvetö fontosságú az Európai Alkotmányos Szerzödés ratifikálása. A cikk írásakor már három tagállam parlamentje (Litvánia, Magyarország és Szlovénia) ratifikálta a dokumentumot. Az elsö népszavazást február 20-án tartja Spanyolország. Az alkotmányos folyamat 2002 februárja és 2004 júniusa között tartott. A cikk megpróbálja áttekinteni, hogy az új tagállamok, különösképpen Magyarország milyen stratégiával vett részt a folyamat elsỏ részében, az. Európai Konvent munkájában. (A Konvent 2002 februárja és 2003 júniusa között tevékenykedett.) A Konvent által elfogadott alkotmánytervezet alapjában véve meghatározta a kormányközi konferencia (IGC) vitáinak kontürjait. A Konvent volt az elsỏ olyan uniós testület, amelyben a 25 tagállam egyenlö jogokkal vehetett részt a tanácskozásokon; ez mintegy elöre vetítette, hogy 2004. május 1. után milyen lesz a kibövuilt Unió müködése.

\section{Megoldható-e egyszerre a bövítés és a demokratikus deficit problémája?}

2004. május 1-jén nyolc egykori kommunista ország találta meg történelmi helyét a kibóvült Európai Unióban. Európa újra egyesülése véget vetett a jaltai rendszer mesterséges megosztottságának, Közép-Európa visszatért Európába. A fent említett mesterséges megosztás megszüntetésének ténye egybe esik az alapító atyák (Monnet, De Gaspari, Schumann) álmával, akik egy olyan Európáról álmodtak, ahol a prosperitás, demokrácia és szolidaritás elvei uralkodnak. Európa újjászületése lezárta a hosszú huszadik századot - a bizalmatlanság és háború évszázadát -, és megnyitotta a huszonegyedik évszázadot, amelyet a remény évszázadának tekinthetünk.

$\mathrm{Az}$ Unió bővülése új esélyeket ad arra, hogy az EU igazi szereplöként jelenjen meg a globális politika színpadán. Olyan eróként, amely képes hatalmas gazdasági erejét politikai erőre lefordítani. Ezt azonban nem lehet megvalósítani egy közös jövőkép nélkül arról, hogy hogyan képzeljük el a nemzetközi rendszer jövőjét (ebből a szempontból kiemelkedő jelentőségü a nemrégiben elfogadott Európai Biztonságpolitikai Stratégia). Természetesen, hogy alkalmasak legyünk a gyorsan változó világhoz alkalmazkodni, meg kell reformálni az Unió döntéshozatali rendszerét is. Erre a kihívásra adhat választ reményeink szerint az Európai Alkotmányos Szerzödés.

A globalizáció kihívásaival - nem utolsósorban a nemzetközi terror elleni küzdelemben - az Uniónak egységesen kell fellépnie. Nem érhet el azonban az Unió 
Grúber Károly : Magyarország és az európai alkotmányozási folyamat: Az Európai Konvent

Tér és Társadalom 19. évf. 2005/1. 155-161. p.

megfelelö eredményeket, ha az Irak kapcsán megrendült transzatlanti kapcsolatokat nem gondoljuk át újra, és nem erösítjük meg ezeket. A Bush elnök újra választása óta eltelt időszakban Washingtonból érkező jelek arra utalnak, hogy van remény és akarat a kapcsolatok javítására. Ezt a tendenciát erősítették meg $\mathrm{C}$. Rice új külügyminiszter és Bush elnök februári európai körútjai.

200 I végére Európában minden szereplö számára világossá vált, hogy a 25 tagúra bővülö Uniót már nem lehet a régi módszerekkel kormányozni. A Nizzai Szerződést elutasító ír népszavazás még világosabbá tette ezeket a tendenciákat. Azért volt különösen sokkoló az ír 'nem', mivel olyan tagállamról volt szó, amely hagyományosan támogatta az integrációt, és a kohéziós és strukturális kifizetések révén az Unió egyik nagy nyerteséröl volt szó. (Az írek számára gyógyír lehet, hogy az Európai Alkotmányos Szerzödést 2004 nyarán éppen az ír elnökség igen taktikus vezetése alatt fogadta el az Európai Tanács. Sok elemzö szerint Bertie Ahern ír miniszterelnök tárgyalási stratégiája nélkül nehezen lehetett volna tető alá hozni a kompromisszumot.) Az ír gazdasági csoda és modernizáció az új tagállamok számára modellként szolgált arra, hogy miképpen lehet az uniós tagságot jól kihasználni a nemzeti felzárkózáshoz. Kétségtelen azonban, hogy az írek elutasítása hozzájárult az Unióban egyre eluralkodó érzéshez, miszerint a brüsszeli intézmények messzebbre vannak az állampolgároktól mint valaha. Anna Vergés Bausili szerint:

„Az ír ratifikáció kudarca nem egy elszigetelt esemény volt, hanem egy jól látható és egyre erősebb tendencia jele arra, hogy az állampolgárok egyre jobban megkérdójelezték az EU legitimációját. A 'nem' arra figyelmeztetett, hogy nem lehet többé adottnak venni az integráció automatikus támogatását még egy olyan társadalomban sem, amely igen sokat nyert az Uniós tagsággal." (Bausili 2003,2)

A 15 tagállam vezetöje által 2001 decemberében elfogadott laeken-i nyilakozat világossá teszi, hogy az Uniónak a fenti kihívások kezelésére új alapszerzödésre van szüksége. A dokumentum kijelenti:

„Az állampolgárok úgy érzik, hogy az Unió túl bürokratikus egy sor terulleten. (...)

Alapvetô kihívás annak megoldása, hogy miképpen tudjuk az állampolgárokat, és különösen a fiatal generációkat, közelebb hozni az európai intézményekhez." (Laeken Declaration ... 2003)

A laeken-i nyilatkozat felhatalmazása alapján kezdte meg a munkáját 2002 februárjában az Európai Konvent. A dokumentum azonban igen pontosan fogalmaz a testület mandátumáról, a Konvent fỏ feladata az alkotmányozási folyamatot lezáró kormányközi konferencia minél jobb elökészítése volt. A végső szót azonban az Unió államfőit magában foglaló Európai Tanácsnak kellett meghozni. A laeken-i nyilatkozat szerint:

„A következö kormányközi konferencia minél jobb és szélesebb körü elökészítése érdekében az Európai Tanács egy olyan Konvent létrehozásáról döntött, amely magában foglalja az összes érintettet. A Konvent feladata az lesz, hogy számba vegye 
Grúber Károly : Magyarország és az európai alkotmányozási folyamat: Az Európai Konvent Tér és Társadalom 19. évf. 2005/1. 155-161. p.

TÉT XIX. évf. 2005 - 1

Kitekintő

157

az Unió előtt álló legfontosabb kihívásokat és az azokra adható intézményi megoldásokat. (...)

A nemzeti viták eredményeinek integrálásával a Konventnek olyan előterjesztést kell létrehoznia, amely megfelelő vitaindító lesz a kormányközi konferencia számára, amely majd meghozza a végső döntéseket." (Laeken Declaration ... 2003)

\section{Új tagállamok a Konventben}

Arra a kérdésre, hogy a Konvent végrehajtotta-e a laeken-i nyilatkozatban meghatározott feladatát, hely hiányában nem kívánok részletesen választ adni, e helyett inkább azt vizsgálnám, hogy milyen szerepet játszottak az új tagállamok, különösképpen Magyarország a szervezet munkájában.

Magyarország kiindulópontja a Konvent munkájában az volt, hogy a fent vázolt kihívásokra csak olyan Európa tud választ adni, amely hatékony és erős. Egy megerősített Unióra sohasem volt olyan nagy szükség, mint a bővítés utáni periódusban. A magyar résztvevök részére a Konvent történelmi fontosságú intézmény volt, mivel itt voltak először egyenrangú felek a régi és új tagállamok. Annak ellenére, hogy a Konvent első időszakában (2002. február és december között) az új tagállamok professzionális és intézményi kapacitásainak jelentős részét lekötötte a csatlakozási tárgyalások utolsó szakasza, az új tagállamok képviselői nélkülözhetetlen tapasztalatot szereztek arról, hogyan lehet együttmüködni és koalíciót építeni a kibövült EU-ban. Nem kétséges, hogy a Konvent során több olyan kapcsolat és személyi ismerettség alakult ki, amelyek később még igen fontosak lesznek a különböző uniós fórumokon. Anna Vergés-Bausilinek teljes mértékben igaza van akkor, amikor azt elemzi, hogy milyen szerepet játszottak ezek a szövetségek a Konvent munkájában:

„A Konventben jelenlévő nagyszámú hálózat sok törésvonalat és többszintủ identitást takart, sokkal többet, mint azt bármilyen kormányközi konferencia kezelni tudná. Több hálózat ad hoc jellegü volt, de akadtak tartósabbak is. Voltak, amelyek szigorúan pártpolitikai alapon szervezödtek, voltak, amelyek specifikus lobbi érdekek körül. Rengeteg ilyen, sokszor egymást átfedö koalíció müködött a Konventben, egy résztvevő sokszor igen sok különbözö szövetségben vett részt." (Bausili 2003, 4)

Szinte minden elemzỏ megpróbálta a Konvent tagjait valami alapján csoportosítani. A legtöbben egyetértenek, hogy a legfontosabb törésvonalak a kis és nagy, az új és régi, illetve a föderalista és szuverenista tagállamok között voltak. Ezek természetesen igen hasznos csoportosítások, de a Konvent valósága ennél sokkal összetettebb volt. Vegyük például az új tagállamokat; Lengyelország magát nagy tagállamnak tartja, míg Málta és Ciprus mikroállamok. A balti államok szuverenitás felfogása kormányközi, igen hasonló a skandináv államokéhoz, míg a magyarok vagy a szlovákok jóval közelebb vannak a föderalista táborhoz. A Konvent záró szakaszában a hat alapító tag (Benelux Államok, Németország, Franciaország, Olaszország) terjesztett elö kompromisszumos megoldást, míg 9 másik tagállam (kicsi és nagy, kormányközi és föderalista) a Nizzai Szerzỏdés fenntartása mellett érvelt. 
Magyarország 10 millió lakosával közepes méretü tagállamnak számít. Ennek megfelelően sok érdeke egybeesik más kis- és közepes méretü tagállammal. Magyarország is aláirta az ún. hasonlóan gondolkozó tagállamok (like-minded countries) nyilatkozatát. Elemzök szerint e szövetség a Konvent egyik leghatásosabb és legjobban müködő szövetségeinek egyike volt. Paavi Lipponen, az akkori finn miniszterelnök, aki a szövetség egyik meghatározó politikusa volt, egy 2002. júniusi bécsi látogatásán a következöképpen jellemezte az együttmüködést:

„A bővítéssel az Unió közép-európai jellege megerösödik. Ausztria szerepe felértékelödik a bővítéssel. Javítani kell az együttmüködést az északi, a balti, Benelux és a közép-európai országcsoport között. Igen sok a közös érdekünk, nem utolsósorban a kis és közepes országok érdekeinek védelme a Konventben."

2003. szeptember 1-jén a 'like-minded' csoport nagy találkozót szervezett Prágában. A találkozón 15 tagország (Ausztria, Csehország, Dánia, Észtország, Finnország, Görögország, Írország, Lettország, Litvánia, Lengyelország, Magyarország, Portugália, Svédország, Szlovákia és Szlovénia) vett részt. Lengyelország részvétele igen érdekes, mert az alkotmányos vita során legtöbbször nagy tagállamként viselkedett Varsó, és a szövetség korábbi szakaszában nem is vettek részt. A résztvevő államok részletes álláspontja sok mindenben különbözött, de volt annyi közös érdekük, hogy bizonyos ügyekben közösen lépjenek fel. (Magyarország álláspontja legközelebb Ausztriához, Finnországhoz és Csehországhoz volt, ennek megfelelöen ez a négy ország alkotta a szövetség belső magját.) A csúcsot lezáró sajtóközlemény is utal erre a közös érdekre:

„A résztvevők nagyra értékelik a Konvent javaslatát. A 'hasonlóan gondolkozó országok' azonban egy sor területen (intézményi kérdések, szavazási modellek, megerösített együttmüködés) fent akarják tartani a változtatás jogát a kormányközi konferencia során."

Összességében elmondható, hogy a Konvent munkája sikeres volt, mert egy sor alapelvben született kompromisszum, ezek a következök:

- egységes szerkezetủ alkotmányos szerzödés,

- az Alapvetö Jogok Kartájának integrálása,

- a 'pillér-szerkezet' megszüntetése,

- a nemzeti parlamentek új szerepköre,

- az Európa Parlament megnövelt hatásköre a Bizottság elnökének megválasztásában,

- új kilépési paragrafus,

- a jogi eszközök egyszerúsítése

- a 'kétkalapú' külügyminiszteri poszt létrehozása.

2003 júniusában az Európai Tanács elfogadta a Konvent javaslatát (amelyet föképpen Valéry Giscard D'Estaing szövegezett). Az európai államfök szerint a Konvent anyaga 'jó vitaindító' az IGC munkájának. Az Európai Tanács thesszaloniki-i döntése szintén biztosította az új tagállamok egyenjogú részvételét a kormányközi 
Grúber Károly : Magyarország és az európai alkotmányozási folyamat: Az Európai Konvent Tér és Társadalom 19. évf. 2005/1. 155-161. p.

konferencián (a döntés előtt az új tagállamok tartottak attól, hogy nem vehetnek teljes joggal részt az IGC-n).

Magyarország uidvözölte ezeket a döntéseket, és tisztában volt azzal, hogy a Konvent anyagának teljes újratárgyalásával patthelyzet alakulhat ki, amely a végső kompromisszumot is veszélyeztetheti. Ezt figyelembe véve a magyar kormány olyan pozíciós papírt fogalmazott meg, amely felvázolta minimális elvárásainkat az alkotmányos szerződéssel kapcsolatban. Ennek főbb elemei a következők:

- Magyarország elvben nem ellenzi a Tanács állandó elnöki posztjának létrehozását. A végsỏ szövegnek azonban világossá kell tenni, hogy milyen lesz a munkamegosztás a Tanács és a Bizottság elnöke, illetve a Tanács elnöke és a külügyminiszter között.

- Magyarország más közepes méretủ tagállamhoz hasonlóan fontosnak tartja a tagállamok egyenjogúságának elvét. Ezért fontos fenntartani az egy tagállam-egy föbiztos szabályt. Elutasítjuk a nem-szavazó főbiztosra vonatkozó javaslatot.

- A csoportos elnökségre vonatkozó javaslatot a tagállamok politikai súlyának és földrajzi fekvésének figyelembevételével kell véglegesíteni.

- A minősített többségre vonatkozó 'kettős többség' elvet akkor tudjuk elfogadni, ha a lakosság küszöb 50\%, míg a tagállamok számára vonatkozó küszöb $60 \%$ lesz.

- A megerősített együttmüködésben részt vevő országok minimumát $1 / 3$ plussz 1-röl 1/2 plussz egyre kell növelni. A 25-tagú EU-ban ez 13 tagállamot jelentene 8 tagállam helyett.

- Az Európai Bíróság hatáskörét ki kellene terjeszteni az Európai Tanács döntéseire, beleértve az intézményi kérdéseket is.

- Az Unió hivatalos nyelveit külön paragrafusban kellene rögzíteni.

- Meg kellene alapozni az Unió kisebbségjogi szabályozását. Magyarország mint többnemzetiségü állam, és melynek kisebbségei millió számra élnek a szomszédos országokban, érdekelt az ilyen jellegü jogalkotásban. Ezt az elvet támogatja Magyarországon minden parlamenti párt. Ezt tiukrözi az a tény, hogy minden magyar konvent tag - akár kormánypárti, akár ellenzéki - támogatta a Konvent ilyen javaslatait, és sokszor maguk jelentkeztek ilyen beadványokkal. ${ }^{1}$

Medgyessy Péter, akkori magyar kormányfö az Európai Tanács thesszaloniki-i ülésén (2003. június 19-20.) javasolta, hogy a kisebbségek kollektív jogait foglalják bele az alkotmányba. Ezt a felvetést a csúcson támogatta a görög és francia(!) államfő is. A végső szövegbe kompromisszumként belekerült a kisebbségi jogok elve, de nem csoportos jogként. 


\section{Következtetések}

Magyar szempontból a Konvent munkája sikeresnek tekinthető. A korábbiakhoz képest az alkotmányozási vita kiszélesedett, sokkal több szereplö vett részt a szöveg megfogalmazásában. Az Európai intézmények szerepe is jóval nagyobb volt, mint korábban az alkotmányozási folyamatban. Az európai civil társadalom is komoly szerepet kapott. Magyarországon azonban sajnos igen korlátozott volt a társadalmi vita. Az alkotmányozási folyamatot legmélyebben elemzö tanulmánykötet szerint:

„A magyar civil szervezetek képviselöi részt vettek az Európai Konvent civil szervezetek képviselöivel kibővített két tanácskozáson. Mindezek ellenére a Konvent érthetöen háttérbe szorult a hazai szélesebb közvélemény érdeklődésében, és csak kis számú kezdeményezö javaslat született a magyar szellemi, tudományos és kutatói körök részéről, amellyel hozzájárultak volna a magyar szempontok megjelenítéséröl az Európa jövőjéröl szóló vitában." (Gordos-Ódor 2004, 21)

A 'like-minded' országcsoport müködése is igen hasznos volt a magyar diplomáciának, mivel ezzel megkezdődött a felkészülés az Unióban oly fontos hatékony koalícióépítésre. Világossá vált, hogy Magyaroszág mérete és fekvése miatt igen aktív szerepet tud majd játszani az Unió közép-európai aspektusának megerősítésében.

Nem kell azonban azt sem letagadni, hogy az iraki konfliktus igen erösen befolyásolta a Konvent és az IGC munkáját. A legtöbb új tagállam kiállt az USA mellett, és igen szkeptikusan látták a 2003. áprilisi belga-francia-német védelempolitikai javaslatot. Magyarország a többi új tagállamhoz hasonlóan azt tartja, hogy továbbra is a NATO az európai biztonság záloga. Az alkotmányos szerzódés végső ESDP-re vonatkozó szövege jó kompromisszum.

Azok az elemzések, amelyek az új tagállamokat passzívitással vádolják a Konvent munkájában, tévesek, mivel a Konvent elsö szakaszában valóban sok intézményi kapacitást kötöttek le a csatlakozási tárgyalások (Cameron-Primatorova 2003). A tárgyalások lezárását követően azonban egyre aktívabbakká váltak.

$\mathrm{Az}$ a tény, hogy az új tagállamok teljes jogú tagként vettek részt a Konventben és késöbb a kormányközi konferencián semlegesítette az új tagok közvéleményének félelmeit a 'másodrangú' tagságról. Alojz Peterle a Konvent szlovén elnökének szavaival élve:

„Nem akartunk - az új tagállamok képviselöi - úgy megjelenni a Konvent találkozókon, mint egy külön csapat. Mi egy közös jövőben gondolkoztunk. Ez volt a Konvent zsenialitása. Nem akart senki egy gyenge és megosztott Európát. Mindannyian hittünk a sikerben." (Peterle 2003, 9) 


\section{Jegyzet}

${ }^{1}$ Minden magyar Konvent-tag támogatta az a javaslatot, amely az alkotmányos szerzỏdés 6. paragrafusára vonatkozott. A javaslat arra irányult, hogy a nemzeti és etnikai kisebbségek jogainak védelme kerüljön be az Unió alapértékei kơzé. Később ez a javaslat beleépỉlt az Európai Tanács által a kormány. közi konferencia után elfogadott szövegébe.

Balázs Péter, a kormány által delegált Konvent-tag a dokumetum 1-57. Paragrafusára tett javaslatot. E szerint az új tagok felvételekor alkalmazott ún. Koppenhágai kritériumok az Unió alapjogának részévé válnak. A Koppenhágai kritériumok elvárjảk az új tagoktól, hogy tartsák tiszteletben a kisebbségek jogait. Ez a javaslat nem került be az alkotmány végsó szövegébe.

Szájer József az ellenzéki FIDESZ delegáltja arra tett javaslatot, hogy az Unió hozzon létre egy olyan konzultatív szervezetet, amely a kisebbségi jogok betartását ellenörizné (The Committee of Ethnic and National Minoritites). Ez a javaslat sem került be az alkotmányos szerződés végsỏ szövegébe.

\section{Irodalom}

Bausili, A. V. (2003) The Consitutional Convention and Ireland. The Federal Trust, London.

Laeken Declaration on the Future of the European Union. (2003) SN 300/1/01 REV 1, Brusszel.

Gordos Á-Ódor B. (2004) Az Európai Alkotmányos Szerzödés sziiletése, Tanulmányok és dokementumok. HVGORAC, Lap- és Könyvkiadó Kft, Budapest.

Cameron, F.-Primatarova, A. (2003) Enlargement, CFSP and the Convention: The Role of of the Accession States. EPIN Working Paper, 5., Brussels.

Peterle. A. (2003) Unique Spirit Born of the Convention musb preserved' - Editorial in European Voice. June, 19-25. 0 . 